\title{
Credit sources, access and factors influencing credit demand among rural livestock farmers in Nigeria
}

Article

Accepted Version

Silong, A. and Gadanakis, Y. (2020) Credit sources, access and factors influencing credit demand among rural livestock farmers in Nigeria. Agricultural Finance Review, 80 (1). pp. 6890. ISSN 0002-1466 doi: https://doi.org/10.1108/AFR-10-20180090 Available at https://centaur.reading.ac.uk/85405/

It is advisable to refer to the publisher's version if you intend to cite from the work. See Guidance on citing.

To link to this article DOI: http://dx.doi.org/10.1108/AFR-10-2018-0090

Publisher: Emerald

All outputs in CentAUR are protected by Intellectual Property Rights law, including copyright law. Copyright and IPR is retained by the creators or other copyright holders. Terms and conditions for use of this material are defined in the End User Agreement.

$\underline{\text { www.reading.ac.uk/centaur }}$ 
Central Archive at the University of Reading

Reading's research outputs online 


\section{Emerald $\begin{gathered}\text { Agricultural } \\ \text { Finance Review }\end{gathered}$}

\section{Credit sources, access and factors influencing credit demand among rural livestock farmers in Nigeria.}

\begin{tabular}{|r|l|}
\hline Journal: & Agricultural Finance Review \\
\hline Manuscript ID & AFR-10-2018-0090.R3 \\
\hline Manuscript Type: & Research Article \\
\hline Keywords: & $\begin{array}{l}\text { Rural farmers, credit demand, credit access, logit model, multinomial } \\
\text { logit model, livestock production }\end{array}$ \\
\hline \multicolumn{2}{|l}{} \\
\hline
\end{tabular}


Topic: Credit sources, access and factors influencing credit demand among rural livestock farmers in Nigeria.

\begin{abstract}
:
Purpose -- Rural farmers' access to farm credit in Nigeria has been very low, which affects farm performance, and credit providers have blamed for the problem in the sector. While this general perception persists, the fact may be the case of credit demand, rather than just the riskaverse attitudes of credit providers. The research, therefore, sets to investigate significant factors influencing farmers' credit demand to ensure efficient credit provision.

Methodology -- The research adopted mixed methods for an in-depth investigation into the problem. There were 216 research participants split into equal halves of men and women from six Local Government Areas of Nasarawa State. Data collection methods employed structured interviews, focus group discussions, close/open-ended, and key informant interviews. Analytical tools involved descriptive statistics, the logit and multinomial logit models to determine participants' socioeconomic characteristics, sources of credit, access, factors influencing credit demand generally, and from the various sources of credit identified.

Findings -- Findings reveal only $47.6 \%$ of the participants accessed credit, with fewer women accessing than men. The most accessed forms of credit are from the semi-formal sources, with more men accessing from formal sources and more women from non-formal sources. Factors having significant influence on credit demand generally are education, group membership and household size. And from formal, semi-formal and non-formal credit sources are 1); education, information on sources of credit, deposits, household size and marital status, 2); education, deposits, group membership, household size, flock size, and 3); education, group membership, and gender from the non-formal credit providers, respectively.
\end{abstract}




\subsection{Introduction}

Scholarly findings from Shahab et al. (2018), Akudugu et al. (2011 and 2012b), Kokoye et al. (2013), and other scholars have professed credit to be a development tool so powerful to capitalize farm households to invest and adopt improved farming methods and production technologies to enhance productivity. Schindler (2010), Akudugu (2011), Deb and Suri (2013), and other scholars acknowledge that credit provides working capital particularly, in rural areas where many of the impoverished people live. Thus, credit is capable of stabilizing household consumption to reduce poverty. Scholarly findings have continued to confirm credit to transform the living conditions of beneficiaries by increasing their farm productivities to enhance income as well as boosting their self-confidence and well-being (Akudugu, 2011; Akudugu et al. (2012b). In Nigeria for example, Ogbuabor and Nwosu (2017), Emesefi and Yusuf (2014), and other scholars acknowledge credit to increase farm output significantly, hence farm family income and help the poor towards accumulating their wealth to invest in farming. It is an instrument that could possibly transform the traditional agricultural sector into modern form and create employment opportunities. Hence, credit is a critical component that could tackle productivity problems and reduce extreme poverty, supporting the generation of self-employment in the rural sector farming and non-farming activities for investment in working capital, and one of the core strategies for alleviating poverty in most developing countries (The World Bank, 2017; Tiken Das, 2018)

Livestock production particularly is known to be of massive importance to the poor and one of the principal components of the rural and national economy. The International Fund for Agricultural Development (IFAD) (2006; 2004) and Food and Agricultural Organisation (FAO) (2017) acknowledge that livestock keeping diversifies production and reduces the risks of economic losses resulting from crops destroyed by adverse climatic conditions or diseases. It is a natural and economic capital which contributes to human diets and livelihoods through home consumption and income generation, acting as a live bank, imparting social status, and providing draft, transport, and fertilizer, especially for resource-poor farmers. If the production of livestock is well integrated into the household economy, it will allow more efficient use of family labour, provide a secure food and cash income spread over the entire year, and manure as fertilizer that improves the soil, thus enhancing crop production (World 
Bank, 2009). Given the relative importance of the livestock sector to rural smallholders, one question that arises is the extent to which farmers access credit to facilitate their taking advantage of developing livestock production and other livelihood activities.

Although agriculture including livestock production remains a vital component of the country's economy contributing about $41 \%$ of GDP, and employing about $70 \%$ of the active population, the agricultural sector receives less than 10\% of the annual budgetary allocations (Ojo and Adebayo, 2012). Consequently, the sector has significantly underperformed over the years, failing to be self-sufficient in supplying food in the quantity and quality to feed the continually growing population. For example, Ojo and Adebayo (2012) report that food production in Nigeria increases at the rate of $2.5 \%$ per annum while population increases at $2.8 \%$ which does not match the demand for food; recorded at $3.5 \%$ per annum. There is widespread food insecurity in the country due to the food demand-supply gap resulting in rising food prices and imports. The most significant problem in the food sector in Nigeria is that of low animal protein in the diets of a large proportion of the population, especially in the rural areas where about $70 \%$ of its population lives (FAO, 2017; Mubarrak et al., 2016). Among other factors responsible for the precarious food insecurity such as land, agricultural research and policy, technology, infrastructure, and access to support services such as extension services; Ojo and Adebayo (2012), and the Federal Ministry for Agriculture and Rural Development in Nigeria (FMARD) (2008) confirm inadequate financing to be the significant problem. For instance, the allocation of credit to the Nigerian agricultural sector by commercial banks declined from about $10.8 \%$ of total lending in 1985 to only about 3.7\% in 2014 (Udoka et al., 2016). Some scholars confirm the declining trend in credit provision by the financial sectors are due to the risks and uncertainties in Nigerian agriculture, especially to small holders (Famogbiele, 2013; CBN, 2014). Hence, financial providers in Africa, including Nigeria, have been criticised for the precarious condition of agricultural production (Alliance for a Green Revolution in Africa, 2012; IFPRI, 2014). While the declining trend of credit allocation to farm households in Nigeria has been reported by many scholars to be a problem of supply, it may factly be the case of demand. Hence, this study seeks to understand the sources of credit to livestock farmers in the region and the main factors influencing their demand for credit. The study used 
quantitative and qualitative methodologies to critically examine the issues at hand, to comprehend better factors that are most likely to lead to farmers' demand for credit in the first place. Findings from the study are triangulated to achieve study objectives properly.

The use of mixed methodologies in researching problems of this nature is rare in Nigeria, especially in Nasarawa state, because scholars most often use quantitative methods alone (see for example; Girei et al., 2016 and Etonihu et al., 2013). The findings from this study are robust and are hoped to enhance knowledge among credit providers in the region about farmers' requirements for credit. Moreover, the policy recommendations would help the government and financial institutions to tackle issues identified while devising financial innovations aimed at sustainably providing credit services tailored to the needs of farmers (IFPRI, 2014; Adeoye and Ugalahi, 2017).

\subsection{Study objectives}

Objective I: Identify and describe the sources and features of credit to small rural holders (particularly livestock farmers)

Objective 2: Determine farmers access to credit

Objective 3: Investigate significant factors influencing farmers decision to borrow from the various credit providers.

\subsection{Literature review}

\subsection{Financing the rural small sector farming in Nigeria}

Small scale production is of enormous importance to economic growth and social development in Nigeria. Notably, the small rural sector is vital for the mobilisation of untapped financial resources, conservation of foreign exchange, utilisation of local resources and could present reliable avenues for economic integration, and the transformation of the traditional sector into modern form, as well as the creation of employment opportunities. According to Owualah (1998), small sector farming provides opportunities for training in skill acquisition to enhance 
proper management of livelihood activities for low-income earners. However, poor access to credit has been affecting its growth. Hanson and Menezes (1971) remarked that people borrow money not because they want it for their own sake but only because it gives them command over goods and services. In other words, nobody will seek a loan unless they consider that the value of the satisfaction to be derived from the goods or services on which the money is to be spent for is at least equal to the interest that must be paid. As such, loan finances accessed by the smallholders could increase family income and help the poor towards accumulating their capital to invest in employment generating activities (Germidis et al., 1991).

\subsection{Credit sources and features in Nigeria}

In Nigeria, the major sources of finance available to rural farmers are categorised into three groups, namely; formal, semi-formal and the non-formal credit institutions. The semi-formal and non-formal credit sources are further categorised as informal credit institutions/markets (Badiru, 2010). Formal credit institutions consist of the country's official and commercial banks such as the Nigerian Agricultural Bank (NAB), the Nigerian Industrial Development Bank (NIDB), the state government-owned credit institutions and Micro Finance Institutions (MFIs), Private and Merchant Banks, and Finance Houses. The semi-formal sources of credit comprise of the NGOs, Cooperative Societies and support groups, farmers' associations and the rotating savings and credit associations (ROSCAs). The final group are the non-formal credit institutions, these sources of credit involve money lenders such as merchants, traders, loan sharks, rural shop keepers, clubs and saving societies like "Esusu"; "Ajo", friends, relatives, spouses and so on (Badiru, 2010; Okojie, 2010).

The formal credit institutions operate in a more structured way, providing financial services to its customers based on membership deposit and collateral. These sources operate under strict and complex rules and conditions for accessing credit and are deposit-based with the 
requirement of physical collateral for security. More straightforward rules operate with formal Micro Finance Institutions, but they also require physical collateral, while the Nigerian Agricultural Bank requires peer collateral. Thus, accessing credit from these institutions require customers to have an account with the banks and tangible or intangible collateral security.

The semi-formal sources of credit in Nigeria are set up, owned and managed by their members. They are also democratically operated, so their policies and programs are set to adapt to the rural environment and their members. These sources of credit were inspired by the non-formal system to better respond to the needs of the rural population and to correct the negative aspects of the non-formal credit markets. The semi-formal sources of credit provide loans to local rural and urban populations who do not have access to formal credit institutions, so that they can obtain loans at conditions suitable to their needs and at rates which are better than the nonformal credit sources (Badiru, 2010; Okojie et al., 2010). Lastly, the non-formal credit sources give loans in cash or in kind to be reimbursed in cash or kind; often in agricultural produce when advanced to farmers. Credit accessed from these sources does not usually require a deposit relationship, and no collateral is required (Badiru, 2010). In Nigeria, generally, commercial banks and other formal credit institutions fail to cater to the credit needs of rural populations because of their lending terms and conditions. It is the rules and regulations of the formal financial institutions that have generated the idea that the poor are not bankable, and since they cannot afford the terms, they are therefore considered not creditworthy (Adera, 1995). Much effort has been invested in overcoming the widespread lack of financial services, especially among small rural holders through the expansion of credit in the rural areas in developing countries, including Nigeria. However, a majority still have limited access to credit, especially from the formal credit institutions to support their private livelihood activities (Okojie et al., 2010 and Badiru, 2010). As such, the informal sector finance remains the major 
sources of credit to the rural sector in Nigeria, which provide easier access to credit facilities for the small rural holders.

\subsection{Demand for credit by the small rural holders in Nigeria and access.}

Many socio-economic factors play an essential role in determining the demand for credit by an individual farmer/entrepreneur. Firstly, it is a preference, which may be influenced by factors such as age, gender, marital status, education, group membership, level of income, and so on. Secondly is the price or cost of the commodity. Thirdly is the borrower's preference among the alternatives available. Just as in the theory of demand for goods and services and prices, the purchasing decisions of consumers and quantity purchased is impacted by the prices of commodities demanded (Saleemi, 2000; Mudida, 2003). In other words, when deciding to borrow, an individual look at the cost of credit, the available alternatives, the conditions of borrowing from alternatives, and the socio-economic characteristics of borrowers. These put together give bases for consideration to borrow from the alternative sources. For example, if borrowing from formal credit sources proves expensive, borrowers are likely to turn to informal sources and vice versa. This is simply on the basis that if the cost of credit goes up, the marginal utility per unit price raised from that credit goes down. The borrower, therefore, chooses to either not consume or consume less of the credit. The concept of utility and marginal utility explains consumer demand on a commodity. The utility is the capacity or power of a commodity to satisfy the desire of a user. If credit borrowed will satisfy the financial needs of a borrower, then credit has utility (Saleemi, 2000). The main objective of any borrower is to maximise satisfaction out of any finances borrowed, given or self-made. As such, the conditions of accessing credit from the alternative markets are taken into consideration before deciding to borrow/access credit. 
Conditions for accessing credit by small rural farmers in Nigeria vary from one credit institution to another. For example, Badiru (2010) reports that the Central Bank of Nigeria's $(\mathrm{CBN})$ guaranteed loans through commercial banks require customers to have an account with the bank with tangible or intangible collateral security (sometimes with savings/deposits). Semi-formal finance institutions provide credit based on membership deposit and peer collateral, and the non-formal credit providers usually do not require a deposit or collateral; however, they charge high-interest rates on the basis that no collateral is provided. Sometimes loans from the non-formal credit institutions may be provided in the form of production inputs. It is estimated that only $2.5 \%$ of total CBN loans and advances are directed to small scale farmers in Nigeria (CBN 2008; Badiru, 2010). Badiru (2010) confirms that credit amounts accessed by farmers from formal credit markets vary from N20, 000.00 (approximately $£ 40.00$, with intangible collateral) and up to N10,000,000.00 (approximately $£ 20,000.00$ with tangible collateral). Credit amounts accessed from RoSCAs, Cooperative Societies, Credit Unions and the NAB vary at any point in time, depending on membership strength and the total contribution by the group. However, average loans from these sources vary from N5, 000.00(approximately $£ 10.00$ ) to $\mathrm{N} 20,000.00$ (approximately $£ 40.00$ ).

The small rural holders in Nigeria have limited ideas about the nature of formal financial systems because they have little or no access to information concerning these sources. Firstly, because most formal institutions perceive small rural holders as high-risk clients because the subsistent nature of their production. Hence, they are hesitant to grant them loans because they do not provide good enough returns. Secondly, with the problem of illiteracy and poor management knowledge, smallholders are discouraged from accessing credit from formal credit institutions because of the administrative procedures, paperwork and provision of guarantors and collateral. Thirdly, formal finance institutions are mostly located in the urban area, hence the transaction costs of transport including interest rates and time spent in an 
application and waiting are usually too high for rural farmers. These factors among others affect the integration of rural farmers into the formal finance system (Okojie et al., 2010). The implication is that most of them access credit from the informal sector which is usually in small amounts, short term with very high-interest charges, untimely supply, and unconducive repayment conditions (Okojie, 2010; Anyanwu, 2004; Badiru, 2010; Philip et al., 2009). As such, farmers may not necessarily derive the benefit required from credit accessed from semiformal credit sources, thus, becoming financially excluded, and dependent only on their own income for productive purposes which is often meagre, rendering their productive activities to be marginal (Okojie, 2010, Fletchner and Kenny, 2011 and World Bank, 2008a).

\subsection{Financial literacy and their implications on credit access}

Financial literacy is about empowering and enlightening consumers so that, they are knowledgeable about finance in a way that is relevant to their lives and enables them to use this knowledge to evaluate financial products and make informed decisions. Moreover, financial education is the process by which financial consumers improve their understanding of financial products and concepts through information, instruction and objective advice to enable them to develop the skills and concepts required to become aware of financial risks and opportunities to make informed choices, and know where to go for financial products to minimise risks (Collins and O'Rourke, 2010). Financially educated consumers would benefit the financial sector to make a useful contribution to real economic growth and poverty reduction. Building financially literate and capable populations through financial education could have enormous future benefits for any economy (Guiso and Viviano, 2015).

Many scholarly findings in Nigeria indicate that most smallholder farmers have a limited understanding of financial products and services. A survey in 2008 showed that about $80 \%$ of Nigerians do not have bank accounts with formal financial institutions which make them 
financially excluded. This is due to their low-income status, low level of education, and low level of financial literacy (Credit Awareness Nigeria.com, 2013).

In a country with a diverse social and economic profile like Nigeria, financial literacy is particularly essential for rural people. A better understanding of how the financial markets work, what they offer, as well as how to utilise financial products could create a viable financial system. Building financial capacity through financial education in Nigeria will help consumers to acquire the skills and knowledge to be confident, self-reliant and capable of making their own financial decisions thereby helping them to assume more responsibility in their financial decisions while minimising risks as they navigate the financial markets to ensure the smooth functioning of the financial markets (Credit Awareness Nigeria.com, 2013).

\subsection{Materials and methods}

\subsection{Description of the study location}

The study location is Nasarawa State in Nigeria, which is centrally located in the middle belt region of the country with state capital in Lafia (Marcus and Binbol, 2010). Nasarawa state falls within the southern guinea savannah zone characterized by a tropical sub-humid climate with two distinct seasons; the wet season, lasting about six months (May - October) and the dry season occurring between November and April, with annual rainfall figures ranging from $1100 \mathrm{~mm}$ to about $2000 \mathrm{~mm}$. Temperatures are generally high during the day, particularly between March and April with mean monthly temperatures ranging between $20^{\circ} \mathrm{C}$ and $34^{\circ} \mathrm{C}$ (Marcus and Binbol, 2010; Rahman et al., 2010). The main economic activity in Nasarawa State is agriculture. The state is rich with fertile agricultural land, rivers, streams, as well as a large active population that can sustain a highly productive agrarian sector. The principal crops grown include maize, rice, sorghum, millet, cowpea, groundnut, yam, cassava, soybeans, oil palm, beniseed, melon, and bambara nuts. The livestock industry plays a very significant role in the physical and socio-economic wellbeing of the population (Rahman et al., 2010), with a considerable number of different livestock species in the state including cattle, goats, sheep, pigs, rabbits and poultry (Ibid). 
Nasarawa state consists of three senatorial districts: west, central and south senatorial districts, and thirteen local government areas. The southern senatorial district includes five LGAs; Karu, Keffi, Kokona, Nasarawa, and Toto. The central senatorial district consists of Akwanga, Nasarawa Eggon, and Wamba LGAs and the western senatorial district consists of Awe, Lafia, Keana, Doma and Obi LGAs (ibid). The state has a total land area of 27,137.8 square kilometres and a population of about 1.8 million people, with a density of about 67 persons per square kilometre (NPC, 2016; Marcus and Binbol, 2010).

\subsection{Approach to the study, data sources and collection strategies, and sampling procedure}

The study adopted the pragmatist paradigm using mixed methodologies in its inquiry. Structured interviews consisting of closed and open-ended questions, focus group discussions (FGDs), and key informant interviews (KIIs) were instruments used for primary data collection. The multistage sampling techniques were adopted for the selection of a total of 216 research participants from six Local Government Areas (LGAs); Obi, Lafia, Nasarawa Eggon, Kokona, Akwanga and Karu, and 18 villages who were used for the survey. Participants of various FGDs conducted were recruited with the help of Fadama III desk officers and livestock assistants of the various livestock units of the six LGAs investigated. There were at least two farmers; men and women from each of the three villages examined in each LGA involved in the FGDs to ensure representation. The KIs were two staff each from credit institutions picked up at random in the LGAs investigated.

\subsection{Field data collection}

First, structured questionnaires consisting of closed and open-ended questions were administered to 216 selected respondents in six LGAs of Nasarawa State, where quantitative and qualitative data were obtained. The survey covered aspects such as the socio-economic characteristics (SECs) of participants, their sources of credit, conditions for accessing credit, and reasons for not accessing credit. Questions were carefully planned and considered beforehand to achieve research objectives and were pre-tested and refined before administering. Interviews enabled the examining of the participants' depth of understanding of the subject matter and were useful with regards to contacting large numbers quickly and replicating interviews to produce standardized and reliable form data. However, because questions 
are predetermined, the depth of responses was limited to the set questions. To upset this; a guide reflecting the study objectives was used for FGDs. Participants of various FGDs conducted were recruited with the help of the desk officers of Fadama III Project and livestock assistants of the livestock units of each of the six LGAs investigated. There were at least two farmers; male and females from each of the three villages investigated in each LGA involved in the FGDs to ensure representation. Through FGDs, members participated in discussions to explore sources of credit, access, factors influencing demand for credit, reasons for not accessing credit and other sources of income for investing in livestock production. Thirdly, KIIs were used to obtain information from carefully selected credit providers who are thought to have in-depth knowledge about credit facilities and mode of access. The KII guide reflected the objectives of the study. KIIs conducted enabled the researcher to acquire some knowledge about the credit facilities available to farmers in the study area and explored further on the conditions these institutions apply when granting loans to farmers. This information was used to determine factors that farmers are likely to consider given the conditions of access and alternatives available to them before deciding to borrow.

\subsection{Data analysis}

\subsubsection{Examining credit sources and features, and factors influencing access}

The various sources of credit, their features and access to farmers have been identified through surveys and KIIs. Also, research participants were asked to indicate the factors that affect their decision to borrow from the different sources identified, and these were corroborated with data from KIIs. Factors identified were then modelled using the logit and multinomial logistic regression models (MNLM).

\section{a. The logit model (LM)}

The study employed the threshold decision-making theory proposed by Hill and Kau (1973) and Pindyck and Rubinfeld (1998), in the logit model. The application of this theory in the context of this study is that; given a specific set of factors; there is a reaction threshold that borrowers must reach before making loan decisions. Thus, at a value of stimulus below the threshold, there will be no decision to borrow, while at the critical threshold value, borrowing is observed.

This reaction is modelled using the relationship: 
$Y_{i}=\beta X_{i}+u_{i}$

Where $Y_{\mathrm{i}}$ is equal to one (1) when a decision is made to borrow and zero (0); otherwise; this means:

$Y_{i}=1$ if $X_{i}$ is greater than or equal to a critical value, $X^{*}$; and $Y_{i}=0$ if $X_{i}$ is less than a critical value, $\mathrm{X}^{*}$

$\mathrm{X}^{*}$ represents the combined effects of the independent variables $\left(X_{i}\right)$ at the threshold level. Equation 1.1 represents a binary choice model involving the estimation of the probability of credit access $\left(\mathrm{Y}_{\mathrm{i}}\right)$ as a function of independent variables $\left(\mathrm{X}_{\mathrm{i}}\right)$.

The empirical model for the logit estimation is specified as follows:

$y_{i}=\log \frac{P_{i}}{1-P_{i}}=\alpha+\beta X_{i}+\varepsilon_{i}$

Where $Y_{\mathrm{i}}$ is the observed response for the $\mathrm{i}^{\text {th }}$ observation of the response variable, $\mathrm{Y}$.

$\log \frac{P_{i}}{1-P_{i}}$ Are the log-odds in favour of farmers' decision to access credit.

$Y_{i}=1$ for farmers who decide to borrow

And

$\mathrm{Y}_{\mathrm{i}}=0$ for those who decide not to borrow), and

$\mathrm{Xi}$ 's $=$ factors that promote or prevent farmers' access to credit; $\mathrm{X}_{1}-\mathrm{X}_{15}$, and are defined as follows:

$X_{1}=$ Age in years $(+)$

$X_{2}=$ Age in years squared (-)

$X_{3}=$ Flock size in numbers $(+)$

$X_{4}=$ Marital status of farmer, dummy $(1=$ Married: $0=$ Single $)(+)$

$X_{5}=$ Collateral requirements (perception), dummy $(1=$ if credit access depends on collateral; $0=$ Otherwise) $(+)$ 


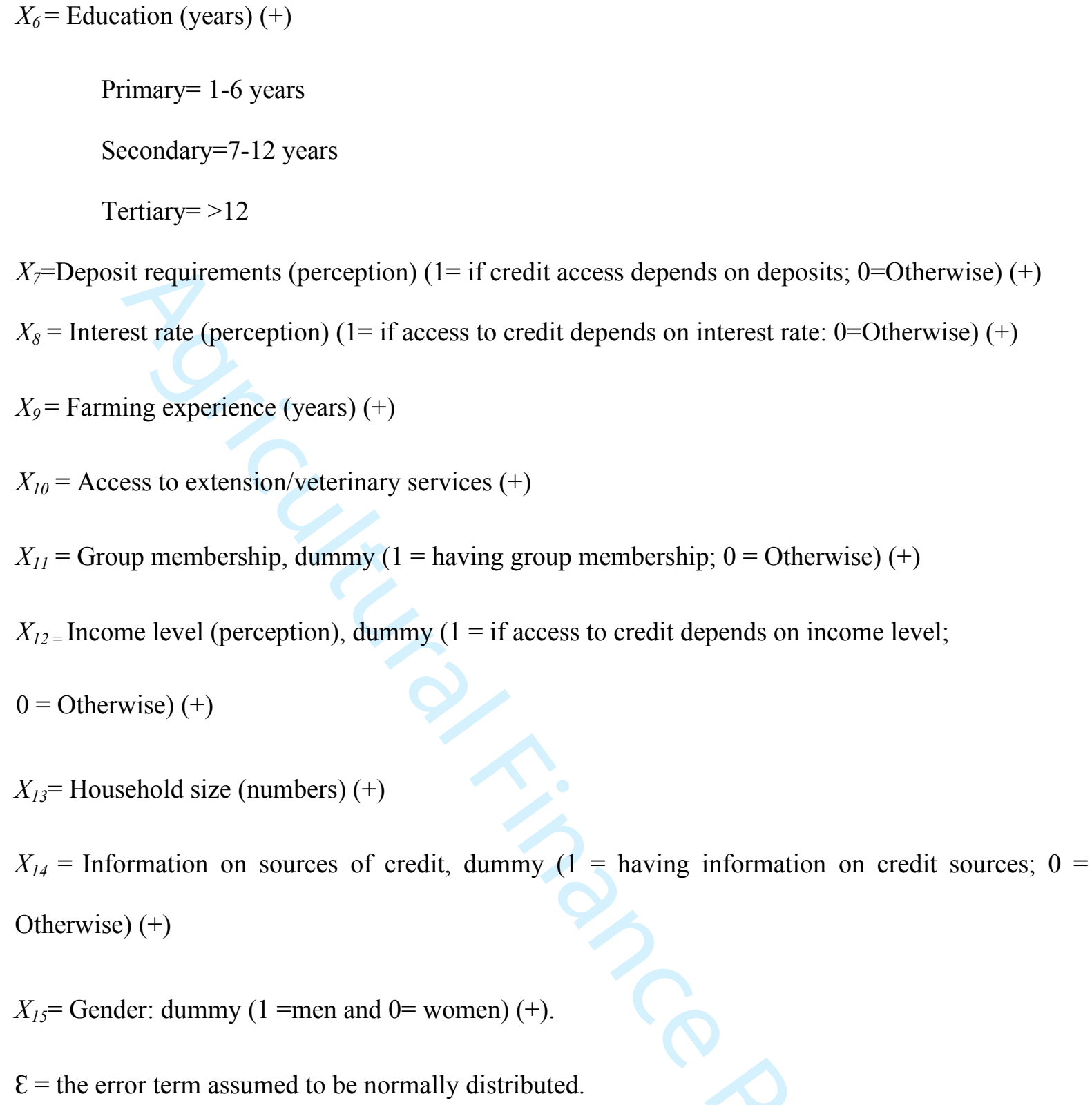

The signs in parentheses indicate the a priori expectations of the direction of change in the probability of access to credit due to a unit change in any of the explanatory factors in the model.

\section{b. The multinomial logit model (MNLM)}

To be able to assess the factors that affect farmers' decision to borrow from either of the three credit sources identified, the MNLM was applied. In this scenario, the decision makers were faced with choices involving more than two alternatives. If a farmer were to access credit from these three choices; formal, semi-formal and non-formal credit sources, which one option does he/she choose? In each of these scenarios, the observed decision is related to a set of explanatory variables. The estimation and 
interpretation of the MNLM are, in principle, like the logit model; to predict the probability that an individual with a particular set of characteristics chooses one of the alternatives. For example, given that a farmer obtained a loan, what is the likelihood that they would choose one of the three alternatives; formal, semi-formal or non-formal credit providers? The factors affecting this choice are variable. As in the logit model, the probability that the ith farmer will choose alternative $\mathrm{j}$ is as follows:

$P_{i j}=\mathbf{P}$ [individual $i$ chooses alternative $\left.j\right]$

With these $\mathrm{j}=3$ alternatives, denoted by $\mathrm{j}=1,2$, or 3 .

Assuming there is a single explanatory factor, $X_{\mathrm{i}}$, then, in the multinomial logit specification, the probabilities of individual $i$ choosing alternatives $j=1,2$, or 3 are:

$$
\begin{aligned}
& P_{i l}=1 \quad, \quad \mathrm{j}=1 \\
& 1+\exp \left(\beta_{12}+\beta_{22} x i\right)+\exp \left(\beta_{13}+\beta_{23} x i\right) \\
& P i 2=-\exp \left(\beta_{12}+\underline{\beta}_{22} x i\right) \quad, \quad j=2 \\
& 1+\exp \left(\beta_{12}+\beta_{22} x i\right)+\exp \left(\beta_{13}+\beta_{23} x i\right) \\
& P_{i 3}= \\
& \exp \left(\beta_{13}+\underline{\beta}_{23} \underline{x i}\right) \\
& \text {, } \mathrm{j}=3 \\
& 1+\exp \left(\beta_{12}+\beta_{22} x i\right)+\exp \left(\beta_{13}+\beta_{23} x i\right)
\end{aligned}
$$

The parameters $\beta_{12}$ and $\beta_{22}$ are specific to the second alternative, and $\beta_{13}$ and $\beta_{23}$ are specific to the third alternative. The parameters specific to the first alternative are set to zero to solve an identification problem and to make the probabilities sum to one. Setting $\beta_{11}=\beta_{21}=0$ leads to the 1 in the numerator of $P_{\mathrm{i} 1}$ and the 1 in the denominator of each part of (1.3). Specifically, the term that would be there is $\exp$ $\left(\beta_{11}+\beta_{21}\right)=\exp \left(0+0 x_{i}\right)=1$. A distinguishing feature of the multinomial logit model in (1.3) is that there are explanatory variables describing the individual, not the alternatives facing the individual. Such variables are individual specifics $\left(\mathrm{X}_{\mathrm{i}}\right)$. To distinguish the alternatives, different parameter values are considered. For example: Let $Y_{i 1}, Y_{i 2}$ and $Y_{i 3}$ be indicator variables representing the choice made by 
individual $i$. If alternative 1 is selected, then $Y_{i 1}=1$ and $Y_{i 3}=0$ and $Y_{i 2}=0$. If alternative 2 is selected, then $Y_{i 1}=0, Y_{i 2}=1$, and $Y_{i 3}=0$. In the MNLM, everyone must choose one, and only one of the available alternatives. As in the logit, the estimation of this model is by maximum likelihood estimation (MLE). Suppose that three individuals choose alternatives 1, 2, or 3, respectively.

\subsubsection{Choice of variables used for the logit and MNL estimation and justification for inclusion}

The age of farmers $\mathrm{X}_{1}$ measured in years is used as a proxy for maturity and experience in farming $\left(\mathrm{X}_{9}\right)$ and implies the potential ability to perform productive work and utilize and repay credit. It is expected that age would have a positive influence on credit access because as farmers grow older, they acquire more experience in production, therefore becoming confident in accessing credit for investment in their productive activities (Shahab et al., 2018 and Fakayode and Rahji, 2009). Age squared $\left(\mathrm{X}_{2}\right)$ was included in the analysis to test for the quadratic nature of age. The assumption is that as farmers grow to pass their economically active age, their involvement in economic activities including accessing productive resources and credit would decline, thus would be negatively associated with access to credit all things being equal. Flock size measured as count of livestock in numbers $\left(\mathrm{X}_{3}\right)$ was included in the model as a proxy for scale of operation which could influence credit access decisions -- increase in scale of operation would increase revenue, thus credit access and vice versa (Jiao et al., 2018; Abedullah et al., 2009). Marital status of farmers $\left(X_{4}\right)$ was used as a proxy for the agency of respondents. Given that in the study area, marital status determines the type of economic activity one engages in and the number of people in a household ( $\mathrm{X}_{13}$; measured in numbers). The expectation was that it would positively influence credit access decisions of farmers, and it was measured as a dummy $(1=$ married and $0=$ single). Household size $\left(\mathrm{X}_{13}\right)$ was included in the model because farmers with large household sizes are more likely to access credit than those with small household sizes because of the possibility of having readily available farm labour from family members which might reduce the cost of production and increase profit to guarantee credit repayment all things being equal (Shahab et al., 2018; Silong, 2017). Collateral $\left(\mathrm{X}_{5}\right)$ was included in the model because most formal lenders require borrowers to provide collateral as security to access credit. This variable was measured as a dummy ( $1=$ where collateral is required and $0=$ otherwise). The expectation was that farmers would be less likely to access credit where 
collateral is required (Ololade and Olagunju (2018). Education $\left(\mathrm{X}_{6}\right)$ is very important in accessing and controlling productive resources including credit and one of the major factors that influence the decision to participate in and access credit (CBN, IFC and World Bank, 2017 and Lukytawati, 2009). Education in this study is considered in the model in three stages (primary education 1-6 years, secondary education; 7-12 years and tertiary education as $>12$ years). The expectation was that acquiring more years of formal education and financial literacy would be associated with an efficient credit application and could increase farmers' probability of accessing credit (Silong, 2017; Shahab et al., 2018). Deposits $\left(\mathrm{X}_{7}\right)$ are deemed important in accessing credit because people who have deposits as savings with lenders can demonstrate that they can generate income to take care of their household needs and still have a surplus (Samson and Obademi, 2018). It was measured as a dummy (1 for farmers who have savings and 0 ; otherwise). It is expected that savings would influence borrowing positively. Interest rate level $\left(\mathrm{X}_{8}\right)$ was included in the model because farmers who perceived that the interest charges by lenders are high are less likely to access credit from them and vice versa. It was measured as a dummy ( 1 for farmers who perceived interest rates to be high and 0 otherwise). Access to extension/veterinary services $\left(\mathrm{X}_{10}\right)$ was measured as a dummy ( 1 for those who have access and 0 ; otherwise). Extension services provide farmers with the technical know-how to confidently engage in farming activities. As such, it is expected that increasing access to extension/veterinary services by livestock farmers would be associated with increases in access to credit (Silong, 2017). Membership of a social/support groups $\left(\mathrm{X}_{11}\right)$ was included in the model because of the group lending approach adopted by many financial institutions, especially in the rural areas. It was measured as a dummy $(1=$ having a membership of social/support group and 0; otherwise), and expected to be positively associated with increases in credit access (Silong, 2017). Income level $\left(\mathrm{X}_{12}\right)$ was included in the model because people who perceive their income levels to be low may decide not to access credit, and the reverse is true. It was measured as a dummy ( 1 for farmers who perceived that their income levels have an influence on their decision to borrow and 0 ; otherwise). Access to information on the available sources of credit $\left(\mathrm{X}_{14}\right)$ was included in the model because knowing where to go for credit is likely to influence borrowing positively. This was measured as a dummy ( 1 for those who access information on available credit sources and $0=$ otherwise). Finally, is 
gender $\mathrm{X}_{15}$; it is included in the model because, in the rural context of Nigeria, men are more likely to decide to access credit than women. This was measured as a dummy ( $1=$ men and $0=$ women).

\subsection{Empirical results}

4.1 Background information about the research participants

Table 1 Descriptive statistics of selected SEC of farmers

\begin{tabular}{|c|c|c|c|c|c|c|c|}
\hline \multirow{2}{*}{ Socio-economic factors } & \multicolumn{3}{|c|}{ Male: $\mathrm{N}=108$} & & \multicolumn{3}{|c|}{ Female: N: 108} \\
\hline & \multicolumn{2}{|c|}{ Frequency } & \multicolumn{2}{|l|}{$\%$} & Frequency & \multicolumn{2}{|l|}{$\%$} \\
\hline \multirow{4}{*}{\multicolumn{8}{|c|}{$\begin{array}{l}\text { Marital status } \\
\text { Single } \\
\text { Married } \\
\text { Education }\end{array}$}} \\
\hline & & & & & & & \\
\hline & & & & & & & \\
\hline & & & & & & & \\
\hline No education & 18 & & $17 \%$ & & 45 & $42 \%$ & \\
\hline Primary education & 24 & & $22 \%$ & & 31 & $29 \%$ & \\
\hline Secondary education & 46 & & 43 & & 20 & $18 \%$ & \\
\hline Tertiary education $n$ & 20 & & $18 \%$ & & 12 & $11 \%$ & \\
\hline \multicolumn{8}{|l|}{$\begin{array}{l}\text { Access to extension / } \\
\text { veterinary services }\end{array}$} \\
\hline \multicolumn{8}{|l|}{ Had access } \\
\hline & 55 & & $51 \%$ & & 40 & $37 \%$ & \\
\hline Had no access & 53 & & $49 \%$ & & 68 & $63 \%$ & \\
\hline \multicolumn{8}{|l|}{ Group membership } \\
\hline \multicolumn{8}{|l|}{ Have no group } \\
\hline Have group membership & \multicolumn{2}{|l|}{22} & \multicolumn{2}{|l|}{$\begin{array}{l}66.7 \% \\
33.3 \%\end{array}$} & 36 & \multicolumn{2}{|l|}{$33.3 \%$} \\
\hline \multicolumn{8}{|l|}{ Access to credit } \\
\hline Not accessed credit & \multicolumn{2}{|l|}{52} & \multicolumn{2}{|c|}{$48.1 \%$} & 61 & \multicolumn{2}{|l|}{$56.5 \%$} \\
\hline Formal credit & \multicolumn{2}{|l|}{22} & \multicolumn{2}{|l|}{$20.4 \%$} & 10 & \multicolumn{2}{|l|}{$9.3 \%$} \\
\hline Semi-formal credit & \multicolumn{2}{|l|}{28} & \multicolumn{2}{|l|}{$25.9 \%$} & 21 & \multicolumn{2}{|l|}{$19.4 \%$} \\
\hline Non-formal credit & 6 & & $5.6 \%$ & & 16 & $14.8 \%$ & \\
\hline & Min & Max & Mean & $\begin{array}{l}\text { Standard } \\
\text { Deviation }\end{array}$ & $\operatorname{Max}$ & Mean & $\begin{array}{l}\text { Standard } \\
\text { Deviation }\end{array}$ \\
\hline Age & 20 & 78 & 38 & 13.6 & 79 & 39 & 12 \\
\hline Household size & 2 & 35 & 14 & 7 & 31 & 14 & 6 \\
\hline Farming experience & 2 & 48 & 9 & 9 & 30 & 7 & 5.5 \\
\hline Formal education & 0 & 17 & 9 & 5 & 16 & 5.3 & 5.3 \\
\hline Flock size & 5 & 91 & 19 & 14.4 & 78 & 16 & 14.6 \\
\hline
\end{tabular}

The study participants were split equally between genders to account for gender differences in SECs as well as in their demand for credit. Descriptive statistics reveal the mean age of the sampled male and 
female farmers to be 38 and 39 years, with a minimum of 20years and a maximum of 78 and 79 years for male and female farmers respectively. Male and female farmers have on average 9 and 7 years of experience in small ruminant production respectively with a minimum of 2 years and a maximum of 48 and 30 years for male and female farmers respectively. $88 \%$ of male and $83 \%$ of female participants are married. Analysis of the household sizes reveal mean household sizes of 14 and 13 for both male and female farmers, with a minimum of 2 per household, and a maximum of 35 and 31 members for male and female farming households respectively, and both genders have household sizes in the range of 1019 members. Many of the sampled female participants have acquired up to 5 years of formal education up to a maximum of 16 years, and up to 9 years for male farmers with a maximum of 17 years. Overall, 144 of the respondents, comprising 72 each of male and female farmers have group membership with the remaining 36 each of male and female participants having none. Also, 56 men corresponding to $52 \%$ of the sample of male participants accessed credit with $20.4 \%, 25.9 \%$ and $5.6 \%$ accessing from the formal, semi-formal and non-formal credit institutions respectively.

On the other hand, 47 females corresponding to $44 \%$ accessed credit with $9.3 \%, 19.4 \%$ and $14.8 \%$ accessing from the formal, semi-formal and non-formal credit institutions respectively in the production years investigated (2010 and 2011). 51\% and 37\% of male and female participants have contacts with extension/veterinary services. The distribution of respondents' flocks' size reared showed an average of 19 for male farmers with a minimum of 5 and a maximum of 91 and an average of 16 with a minimum of 5 and a maximum of 78 for women. Findings also reveal that $31 \%$ of women had flock sizes in the range of 6-10 compared to $33 \%$ of men having flock sizes in that range. 


\subsection{Sources of credit to research participants and their features}

Table 2 Credit sources and access by gender

\begin{tabular}{|c|c|c|c|c|c|c|c|c|c|}
\hline \multirow[t]{2}{*}{$\begin{array}{l}\text { Credit } \\
\text { institutions }\end{array}$} & \multicolumn{2}{|c|}{ Men $\mathrm{N}=108$} & \multirow[t]{2}{*}{$\begin{array}{l}\text { Men } \\
\text { with } \\
\text { access } \\
\text { to } \\
\text { credit } \\
\mathrm{N}=56 \\
\%\end{array}$} & \multicolumn{2}{|c|}{ Women: $\mathrm{N}=108$} & \multirow[t]{2}{*}{$\begin{array}{l}\text { Women } \\
\text { with } \\
\text { access } \\
\text { to credit } \\
\mathrm{N}=47 \\
\\
\%\end{array}$} & \multicolumn{2}{|c|}{ Total $\mathrm{N}=216$} & \multirow[t]{2}{*}{$\begin{array}{l}\text { Total } \\
\text { men } \\
\text { and } \\
\text { women } \\
\text { with } \\
\text { access } \\
\text { to } \\
\text { credit } \\
\mathrm{N}=103 \\
\%\end{array}$} \\
\hline & Frequency & $\%$ & & Frequency & $\%$ & & Frequency & $\%$ & \\
\hline $\begin{array}{l}\text { Formal } \\
\text { credit } \\
\text { institutions }\end{array}$ & 22 & $20 \%$ & $39 \%$ & 10 & $9 \%$ & $21 \%$ & 32 & $15 \%$ & $31 \%$ \\
\hline $\begin{array}{l}\text { Semiformal } \\
\text { credit } \\
\text { institutions }\end{array}$ & 28 & $26 \%$ & $50 \%$ & 21 & $19 \%$ & $44 \%$ & 49 & $23 \%$ & $48 \%$ \\
\hline $\begin{array}{l}\text { Non- } \\
\text { formal } \\
\text { credit } \\
\text { institutions }\end{array}$ & 6 & $6 \%$ & $11 \%$ & 16 & $15 \%$ & $34 \%$ & 22 & $10 \%$ & $21 \%$ \\
\hline Total & 56 & $52 \%$ & $100 \%$ & 47 & $44 \%$ & $100 \%$ & 103 & $48 \%$ & $100 \%$ \\
\hline
\end{tabular}

Study findings reveal three primary providers of credit to farmers; the formal, semi-formal and nonformal credit providers, and farmers have choices of where to access credit. Official providers of credit comprise the commercial banks (private, and public or government banks, and the NAB). Semi-formal credit providers comprise of NGOs, farmers' social/support groups and cooperatives, the rotating savings and credit associations (ROSCAs), the Fadama groups, and faith organizations. And the nonformal credit providers to farmers comprise friends, relatives, spouses, merchants, village shopkeepers, traders, and other money lenders. The formal credit lenders are primarily made up of the formal financial institutions, specifically official banks licensed to operate as such. These credit providers operate within formal environments and have structured procedures that borrowers and depositors are required to follow to access financial products and services. These laid down systems are regulated and supervised by the central bank of Nigeria (CBN); financial services and products that these financial institutions provide include savings, credit, and insurance, among others. Formal credit providers such as banks often offer large sums, and their loan conditions are such that rural farmers often find it difficult 
to meet --this is mainly due to unnecessary administrative procedures that the farmers, especially women, find difficulty managing because of their low level of educational attainment.

Descriptive analysis reveals that the average years of formal education acquired by women is five years compared to nine years for men (see Table 1). Thus, farmers, especially women, are more likely to struggle with paperwork and administrative procedures (Fletschner and Kenny, 2011; Fletschener, 2009; Okojie et al. 2010). According to KIIs, the issues of high interest rates charged by institutional lenders especially the commercial banks and the need for borrowers to pledge real collateral as security before credit is accessed also results in many rural farmers being excluded from form credit systems as smallholders (IFPRI, 2014). The semi-formal credit providers consist of microfinance institutions, credit unions, financial NGOs, RoSCAs and farmers' cooperatives and social/support groups. These quasi-financial institutions are licensed to operate with less stringent requirements compared to the formal financial institutions. Specifically, the RoSCAs and other support groups provide loans to farmers who are registered members. These groups obtain funds by pooling resources from the registered members over time through savings, which are usually disbursed at a cost (interest rate charges), to members in need. Other ways by which social groups provide loans to their members is by pooling capital resources from individual members to make deposits in private, public or government bank accounts or accounts of faith-based organizations and NGOs, and as groups attract lump sums of money which are disbursed to interested members at a price. These groups may also present joint collateral to institutional lenders to attract lump sums of loans, which are usually paid to interested members, and repayments made at the agreed period with interest charges.

Non-formal credit providers are made up of friends, spouses, relatives, and moneylenders, such as rural shopkeepers, traders, and merchants. These credit providers play a crucial role in financing the activities of farmers. Loans given to farmers by non-formal lenders are usually in forms of cash or production inputs (most often drugs, vaccines and other agro-chemicals from shopkeepers) and are preferable because of proximity and timeliness of delivery. That notwithstanding, credit from non-formal providers are short-term and are most often associated with high costs, especially if borrowed from moneylenders or merchants (Badiru, 2010; Okojie et al., 2010). 
Quantitative findings reveal the dominant sources of credit to participating farmers are those accessed from semi-formal credit providers (48\% access), followed by formal credit providers $(31 \%)$ and the least are those obtained from the non-formal credit providers $(21 \%)$, with more males $(52 \%)$ than females (44\%) accessing credit during the production years investigated. Also, 39\%, 50\% and 11\% of male participants obtained credit from formal, semi-formal and non-formal credit providers respectively, and $21 \%, 44 \%$ and $34 \%$ of female participants did that from the formal, semi-formal and non-formal credit providers respectively. Except for non-formal credit, fewer women had accessed credit from the formal and semi-formal credit providers in comparison to men. This finding is consistent with those of Quisumbing and Pandolfelli (2009), Philip et al. (2009) and Saka et al. (2008), who also confirm female farmers' lower access to credit in comparison to men in Sub-Saharan Africa and Nigeria. This is attributed to several factors including lack of ownership and control over productive assets such as land and equipment to offer as collateral, as well as limited education, mobility, and more importantly cultural and social barriers (Rossi and Lambrou, 2008; Quisumbing and Pandolfelli, 2009). Qualitative findings support this; many farmers acknowledged that semi-formal lenders can be easily accessed due to proximity and are prompt in credit delivery; more so, their repayment conditions are flexible and could be negotiated and renegotiated. This, as in the empirical literature helps to overcome some of the critical barriers to accessing credit by rural people (Okojie et al., 2010; Fletschner and Kenny, 2011; Quisumbing and Pandolfelli, 2009).

\subsection{Factors influencing participants' demand for credit}

The logit model has been used to analyse factors generally influencing participants' demand for credit. The application of the logit theory in the context of this study is that given a particular set of factors, there is a reaction threshold that borrowers must reach before making loan decisions. Thus, at a specific value of stimulus below the threshold, the individual will not decide to borrow while at the critical threshold value, a reaction is stimulated, and borrowing is observed.

\section{Table 3 Logistic regression results of farmers' access to credit}




\begin{tabular}{|c|c|c|}
\hline \multirow[t]{2}{*}{ Factors } & \multicolumn{2}{|c|}{ Logit model } \\
\hline & Coefficients & Standard Error \\
\hline Age & 0.012 & 0.014 \\
\hline Age Square & -0.000 & 0.000 \\
\hline Flock Size & 0.001 & 0.002 \\
\hline Marital Status & -0.019 & 0.092 \\
\hline Collateral & -0.036 & 0.094 \\
\hline Primary Education & $0.313 * * *$ & $0.084 * * *$ \\
\hline Secondary Education & $0.491 * * *$ & $0.084 * * *$ \\
\hline Tertiary Education & $0.626 * * *$ & $0.101 * * *$ \\
\hline Deposit & 0.107 & 0.070 \\
\hline Interest Rate & 0.041 & 0.076 \\
\hline Farming Experience & -0.001 & 0.005 \\
\hline Extension \&Veterinary services & 0.11 & 0.094 \\
\hline Group membership & $0.119 * * *$ & $0.069 * * *$ \\
\hline Income level & -0.014 & 0.085 \\
\hline Household size & $0.010 * *$ & $0.005 * *$ \\
\hline Information on credit sources & 0.047 & 0.086 \\
\hline Gender & -0.129 & 0.069 \\
\hline Constant & -0.404 & 0.330 \\
\hline
\end{tabular}

***sig. at $1 \%, * *$ sig. at $5 \%$. $*=$ sig.at $10 \%$

Results on Table 3 reveal farmers' decision to access credit is significantly influenced by their education (primary, secondary and tertiary education all significant at $1 \%$ levels), group membership (sig. at 1\%) and household size (sig.at 5\%). For a participant farmer that has attended primary education versus a participant with no education, the log of odds of accessing credit increases by 0.313 . Similarly, the $\log$ of odds will increase by 0.491 and 0.626 for those that have attended secondary and tertiary education respectively; and all are statistically significant at $1 \%$ level of significance. Based on the preceding, it is expected that acquiring more years of formal education will be positively associated with a decision to borrow, access to credit and vice versa. To bolster this, qualitative findings reveal loans from the official credit providers are extended to only people who are involved in waged labour and have accounts with the banks through which their salaries are deposited. Most often, those involved in waged labour would have acquired at least 12 years of formal education and would have had bank accounts opened through which their wages are received. It is also expected that obtaining formal education would be positively associated with financial literacy required to be efficient with application processes and the use of credit. Participants with group membership versus those with no membership change the $\log$ of odds by 0.119 of accessing and this is significant at the $1 \%$ level of statistical significance. Higher 
household size influences the probability of credit access positively, for the fact that there would be readily available family labour among farmers with higher household sizes for timely execution of important farm activities, this would reduce costs of production and contribute to higher yields which will guarantee loan repayment. Specifically, as expected, it was found that as farmers grow to pass their economically active age group due to old age (age squared), they are less likely to access credit, as they do not expect to be productive enough to pay back credit borrowed. Also, women who are single are less likely to access credit. Qualitative findings revealed that single women have no husbands to stand in for them to guarantee access to credit. It is also expected that participants who are single would be less likely to borrow as they may not have large household sizes expected to provide the labour requirement on their farms. This is very likely as qualitative findings reveal the major source of labour in the study area is household labour. When farmers are required to provide collateral to be able to access credit, their probability of accessing credit is negatively affected. Farmers and KIs generally indicated that collateral requirement is mostly a constraint to accessing credit -- some farmers admit they do not want to pledge collateral to the banks as they fear to lose them in case of anything going wrong. They believe the landed properties they own belong to their immediate and extended families and should pass it on from generation to generation, and for that, will not relegate control to lenders for whatever reason.

Contrary to the a priori expectations, farming experience failed to lead to increases in access to credit; thus, increases in years of farming experience may entail increases in flock sizes, and rural farmers may not see the need to borrow to invest on their farms for increased proceeds. Increase in farming experience could be used as a proxy for increases in age, which at some point (age square as the study specifies) would decrease efficiency and influence borrowing negatively. Qualitative findings from some male farmers who have failed to borrow reveal borrowing is against their religion as Muslims, and others did say they have enough flock numbers and landed properties for their children to inherit when they pass on, as such, would not want to lose their dignity by having their debtors harass their children after death.

\subsection{Exploring factors influencing access to credit from the existing credit providers}


The multinomial logit model (MNLM) has been applied in this context because the research participants are faced with more than two alternatives, i.e., if a farmer were to access credit from any of the three alternatives; formal, semi-formal and non-formal credit institutions, what would be the probability of accessing credit from either one given that there are factors influencing such decisions? In each of these cases, the observed choice is related to a set of explanatory variables. The MNLM specifically predicts and explains the probability that an individual with a certain set of characteristics chooses one of the 3 alternative credit markets; $\mathrm{Y} 1, \mathrm{Y} 2$, and $\mathrm{Y} 3 . \mathrm{Y} 1=$ formal credit institutions, $\mathrm{Y} 2=$ semi-formal credit institutions, $\mathrm{Y} 3=$ non-formal credit institutions, and $\mathrm{Y} 4=$ non-access respectively. 
Table 4. Factors influencing access to credit from various credit providers (MNLM)

\begin{tabular}{|c|c|c|c|c|c|c|c|c|c|c|c|c|}
\hline & \multicolumn{4}{|c|}{$Y_{1}$ (Formal credits institutions) } & \multicolumn{4}{|c|}{$\mathrm{Y}_{2}$ (Semi formal credit institutions) } & \multicolumn{4}{|c|}{$\mathrm{Y}_{3}$ (Non-formal credit institutions) } \\
\hline & \multirow[b]{2}{*}{ Coefficients } & \multirow[b]{2}{*}{$\begin{array}{l}\text { Standard } \\
\text { Error }\end{array}$} & \multicolumn{2}{|c|}{ Marginal Effects } & \multirow[b]{2}{*}{ Coefficients } & \multirow[b]{2}{*}{$\begin{array}{l}\text { Standard } \\
\text { Error }\end{array}$} & \multicolumn{2}{|c|}{ Marginal Effects } & \multirow[b]{2}{*}{ Coefficients } & \multirow[b]{2}{*}{$\begin{array}{l}\text { Standard } \\
\text { Error }\end{array}$} & \multicolumn{2}{|c|}{ Marginal Effects } \\
\hline & & & Coefficients & $\begin{array}{l}\text { Standard } \\
\text { Error }\end{array}$ & & & Coefficients & $\begin{array}{l}\text { Standard } \\
\text { Error }\end{array}$ & & & Coefficients & SE \\
\hline Age & 0.113 & 0.140 & 0.000 & 0.011 & 0.166 & 0.114 & 0.011 & 0.012 & 0.251 & 0.200 & 0.013 & 0.014 \\
\hline Age Square & -0.001 & 0.002 & -0.000 & 0.000 & -0.001 & 0.001 & -0.000 & 0.000 & -0.003 & 0.003 & -0.000 & 0.000 \\
\hline Flock Size & 0.002 & 0.020 & -0.000 & 0.001 & 0.011 & 0.016 & 0.000 & 0.001 & 0.032 & $0.018^{*}$ & 0.002 & $0.001 *$ \\
\hline $\begin{array}{l}\text { Marital } \\
\text { Status }\end{array}$ & -2.412 & $1.337 *$ & -0.228 & $0.111 * *$ & 0.438 & 0.740 & 0.102 & 0.081 & 0.608 & 0.742 & 0.060 & 0.050 \\
\hline Collateral & 1.244 & 0.904 & 0.118 & 0.074 & -0.026 & 0.658 & -0.019 & 0.071 & -0.864 & 0.818 & -0.075 & 0.056 \\
\hline $\begin{array}{l}\text { Primary } \\
\text { Education }\end{array}$ & 1.543 & $0.901 *$ & 0.043 & 0.073 & 3.062 & $0.787 * * *$ & 0.293 & $0.081 * * *$ & 1.085 & 0.844 & 0.004 & 0.058 \\
\hline $\begin{array}{l}\text { Secondary } \\
\text { Education }\end{array}$ & 2.627 & $0.862 * * *$ & 0.110 & 0.661 & 3.625 & $0.831 * * *$ & 0.306 & $0.081 * * *$ & 2.343 & $0.830 * * *$ & 0.073 & 0.053 \\
\hline $\begin{array}{l}\text { Tertiary } \\
\text { Education }\end{array}$ & 3.705 & $1.007 * * *$ & 0.192 & $0.073 * * *$ & 3.761 & $0.918 * * *$ & 0.277 & $0.086 * * *$ & 3.186 & $0.936 * * *$ & 0.120 & $0.054 * *$ \\
\hline Deposit & 0.227 & 0.576 & -0.009 & 0.044 & 1.716 & $0.544 * * *$ & 0.221 & $0.052 * * *$ & -1.514 & $0.732 * *$ & -0.144 & $0.047 * * *$ \\
\hline Interest Rate & 0.426 & 0.650 & 0.038 & 0.055 & -0.206 & 0.552 & -0.042 & 0.060 & 0.368 & 0.679 & 0.026 & 0.047 \\
\hline $\begin{array}{l}\text { Farming } \\
\text { Experience }\end{array}$ & -0.080 & 0.064 & -0.007 & 0.005 & 0.024 & 0.035 & 0.005 & 0.004 & -0.056 & 0.077 & -0.003 & 0.005 \\
\hline $\begin{array}{l}\text { Extension \& } \\
\text { Veterinary } \\
\text { services }\end{array}$ & 0.589 & 1.003 & 0.023 & 0.084 & 0.919 & 0.796 & 0.084 & 0.086 & 0.346 & 0.836 & 0.001 & 0.057 \\
\hline $\begin{array}{l}\text { Group } \\
\text { membership }\end{array}$ & -0.010 & 0.592 & -0.070 & 0.442 & 1.988 & $0.529 * * *$ & 0.199 & $0.048 * * *$ & 1.647 & $0.705 * *$ & 0.081 & $0.046^{*}$ \\
\hline Income level & -0.593 & 0.710 & -0.054 & 0.058 & -0.238 & 0.575 & -0.028 & 0.062 & 0.859 & 0.875 & 0.072 & 0.061 \\
\hline $\begin{array}{l}\text { Household } \\
\text { size }\end{array}$ & 0.128 & $0.038 * * *$ & 0.009 & $0.003 * * *$ & 0.070 & $0.038^{*}$ & 0.005 & 0.004 & -0.009 & 0.052 & -0.003 & 0.003 \\
\hline $\begin{array}{l}\text { Information } \\
\text { on credit } \\
\text { sources }\end{array}$ & 1.200 & $0.521 * *$ & 0.137 & $0.043 * * *$ & -0.886 & 0.704 & -0.116 & 0.073 & 0.904 & 0.968 & -0.061 & 0.066 \\
\hline Gender & -0.237 & 0.609 & 0.020 & 0.048 & -0.825 & 0.531 & -0.052 & 0.055 & -1.927 & $0.729 * * *$ & -0.121 & 0.049 *** \\
\hline
\end{tabular}

$* * *$ sig. at $1 \%, * *$ sig.at $5 \% . *=$ sig.at $10 \%$ 


\subsection{Factors influencing access to credit from formal credit providers}

Results in Table 4 indicate as farmers go beyond their economically productive years (age square), they are less likely to access credit from formal credit providers. This conforms to Akudugu et al. (2009a) and Akram et al. (2008) who reported the significance of years of age in credit delivery and access. Contrary to the a priori expectations, flock size was found to be negatively associated with the probability of farmer's access from formal credit providers, this again may be due to increases in returns from their farms due to large flock sizes, thus farmers may not see the need for borrowing; however, this is not statistically significant. Marital status of farmers has a negative relationship with access to credit from formal lenders, meaning that for a participant that is single versus a participant who is married, the log of odds of accessing credit from formal credit providers decreases by 1.337 and it is statistically significant at $10 \%$ level of significance. The implication in this study is that farmers who are married are more likely to access credit from formal credit providers than those who are single. Qualitative findings confirm that single women could not access credit because they lacked the support normally granted by spouses in the application process; -- husbands who have agreed their wives' access to credit would normally act as guarantors and support the application processes for their spouses to access credit. The variable of collateral failed to conform to the a priori expectations of having a negative influence on access to credit from formal credit providers. This means that having collateral influenced the probability of access for farmers who borrowed from formal credit providers; however, results indicate that it is not statistically significant. Education at all levels; primary, secondary and tertiary education conformed to the a priori expectation of positive influence on the probability of access to credit from formal credit providers. For a participant that has attended primary education versus a participant with no education, the log of odds of accessing credit from formal credit providers increases by 0.901 , and it is statistically significant at $10 \%$ level of significance. Similarly, the log of odds will increase by 0.862 and 1.007 for those that have secondary and tertiary education respectively and are both statistically significant at $1 \%$ level of significance. Deposits made with formal credit providers met the a priori expectation of a positive relationship with 0.576 probabilities of farmers accessing credit from them. Due to the savings before credit policy by most formal credit institutions, people who saved 
with them mostly demanded credit since the principal motive for saving with them is to get credit in return. This finding of a positive effect of savings on the probability of demanding credit from the formal credit providers are confirmed by Akudugu et al. (2009b) and Akram et al. (2008), however, this not statistically significant. The perception of high-interest rates did not deter farmers from accessing credit from formal credit providers as well. Contrary to what is expected and although not statistically significant--as farmers acquire more years of farming experience, they are less likely to access credit from formal credit institutions. Farmers' exposure to extension services is positively associated with access to credit from formal credit providers but not statistically significant in determining access from these sources in the study area. But for a participant who has access to information on sources of credit versus a participant who has none; the log of odds of accessing credit increases by 0.521 and it is statistically significant at $5 \%$ level of significance. This is expected because those who have information about sources of credit are equipped with the knowledge to make informed choices about where they access to credit. Group membership did not conform to the a priori expectation of access to credit from formal credit providers; however, this is not statistically significant - study findings reveal a majority of the farmers' accessed credit from the support groups they belong to. Contrary to expectation, farmers' perception that those who have high-income access credit from formal credit institutions do not apply in this study as they would rather invest from their income than access credit from these sources. As expected, increases in household size increases the probability of farmers' access to credit from formal credit providers, due to readily available family labour supply in such households, findings indicate that the log of odds of accessing credit from formal credit providers by farmers who have large household sizes increases by 0.038 , this is statistically significant at $1 \%$ level of significance. The gender of participants also conforms to the a priori expectations and confirmed by study findings. This implies that rural female farmers are less likely than their male counterparts to access credit from formal credit providers, this is, however, not statistically significant. This finding is consistent with Quisumbing and Pandolfelli, 2009; Fletschner and Kelly (2011). 


\subsection{Factors influencing access to credit from semi-formal credit providers}

Factors which have significantly determined farmers' access to credit from semi-formal institutions are education at all levels, deposit, group membership, and household size (see Table 5.3). This indicates that for a participant that has attended primary education versus a participant with no education the log of odds of accessing credit from semi-formal credit institutions increases by 0.787 . Similarly, the log of odds will increase by 0.831 and 0.918 for those that have attended secondary and tertiary education respectively and are all statistically significant at $1 \%$ level of significance. Likewise, the log of odds of accessing credit from semi-formal credit sources for participants who have deposits and group membership versus the ones who have not increased by 0.544 and 0.529 respectively, and all are statistically significant at $1 \%$ level of significance. For participants who have no group membership, the $\log$ of odds of accessing credit decreases by 0.062 , and this is statistically significant at $1 \%$ level. The study investigated 72 male and female farmers each who have a membership of cooperatives or social grouping (see Table 1). Members of such groups' pool financial and human capital required for running the association, with the aim of providing affordable services to members. Both quantitative and qualitative findings also suggest that the major sources of credit to men and women are those accessed from semi-formal credit providers; most often the social groups, cooperatives, and rotating credit associations and NGO's in which farmers have a membership. This finding has also been confirmed by as Samson and Obademi (2018) in Nigeria and Akudugu $(2010,2011)$ in Ghana. Deposits/savings made with semi-formal credit institutions by farmers met the a priori expectation of a positive relationship with the probability of farmers accessing credit from them. Akudugu et al. (2009b) and Akram et al. (2008) acknowledged that savings form a basic requirement of accessing credit from semi-formal credit institutions, besides, this is the dominant sources of credit to participants and qualitative findings reveal deposit is the major requirement for access. As expected, the log of odds of participants with large household sizes accessing credit from semi-formal credit institutions increases by 0.038 , and it is statistically significant at $10 \%$ level. Again, this might be due to readily available family labour supply in such households. Although not statistically significant in determining the probability of access to credit from semi-formal credit sources, farmers access to information on sources of credit and their gender influenced their access to these sources positively. 


\subsection{Factors influencing access to credit from non-formal credit providers}

Factors that have a significant positive influence on participant's probability of accessing credit from non-formal credit providers were flock size, education at the secondary and tertiary levels and group membership (see Table 4). The log of odds of accessing credit from non-formal credit institutions for participants with large flock sizes versus the ones with small flock sizes would increase by 0.018 , and this is significant at the $10 \%$ level of significance. The ability to have large flock sizes gives the confidence to borrow from these sources because of the ability to repay credit and sometimes in kind with livestock as it is normally the case in the study area (KIIs and FGDs). Findings reveal the log of odds of borrowing increases by 0.830 for farmers who have more than six years of education and up to 0.936 for farmers who have attained tertiary education, and these are both statistically significant at $1 \%$ level of significance. As expected, group membership positively influenced the probability of farmers' access to credit from these sources and the log of odds increases by 0.705 for farmers who have group membership. Farmers express the views that group membership means that one has the social capital and recognition in the village and therefore could easily access credit from money lenders. FGD participants and KIs emphasized the point that borrowing from non-formal credit providers is very much dependent on relationships and social networks, hence the link with group membership. Factors that have significantly affected access negatively were deposits and gender. Findings indicate that where farmers have savings somewhere, they are less likely to access credit from these providers. Both quantitative and qualitative findings reveal - women are more likely to demand credit from non-formal credit markets than men.

Overall, the MNLM results gave an adjusted R2 of 0.32 , which means that all the independent variables included in the model could explain about $32 \%$ of the variations in probability of farmers accessing credit from these sources. The log likelihood ratio (LR) statistic was found to be significant at $1 \%$, and this means that all the factors included in the MNLM estimation jointly influence the probability of farmers' accessing credit from these sources.

\subsection{Conclusion and policy recommendation}


The study used the multistage sampling technique to select 216 participants; 108 each of male and females from 18 villages across the state based on the information obtained from the state ministries of agriculture and cooperatives. The research adopted the pragmatists' paradigm to its inquiry employing individual interviews through questionnaire administration, FGDs, and KIIs. A total of 12 FGDs were also held with farmers across the sampled villages. Also, 10 KIs from selected credit providers across the study area were interviewed. The research used several research techniques, procedures, and strategies based on the mixed methods paradigm, and employed analytical techniques at different social strata to achieve its objectives. As such, the study used a robust approach regarding methodology to ensure that valid and reliable results are obtained.

The study identified three primary sources of credit to participating small ruminant farmers; the formal, semi-formal and non-formal credit sources. The semi-formal credit lenders are the dominant sources of credit to participants with about $48 \%$ accessing credit from them. It was found that only $31 \%$ and $21 \%$ of participants obtained credit from formal and non-formal credit providers respectively. Further analysis by gender reveals more male than female participants accessed credit during the production years involved, however, more men than females accessed credit from formal and semi-formal credit providers, while more women accessed credit from the non-formal credit providers. Based on these findings, it is concluded that there is a low level of access to credit from the identified sources by farmers and women are more at a disadvantage in accessing credit services, especially from the formal credit providers.

Among the factors investigated which influence participants access to credit generally, the logit findings reveal that education, group membership and household size among others were positively and significantly associated with participants' probability to obtain credit. Among factors found to be significantly associated with access to credit from the formal credit lenders, the MNLM findings reveal significant factors to be education, information on credit sources, deposits, household size, and marital status. 
For those who accessed credit from semi-formal credit providers; education, deposit, group membership, and household size were factors that significantly influenced their access. Factors that have a significant positive influence on participant's access to credit from non-formal credit institutions were flock size, education, deposits, group membership and gender As such, policies aiming to improve credit access among farmers in the study area must target these principal factors. Firstly, it would be helpful to encourage and support the creation of farmers groups and encourage their participation through good leadership to create a conducive environment for learning. These groups could involve experts to provide relevant training and the support required from the various institutions providing services. These could be in the form of training to acquire new skills and knowledge on improved farming methods, financial literacy; and information on financial products and services, in accessing markets for inputs/outputs and services. Also, social network through group membership act as a conduit for useful information sharing which is critical in mediating the relationship between an institutional framework and financial inclusion (George et al., 2018). More so, group membership enables members to derive the benefits associated with social collateral. In developing information content and advertising materials, effort should be taken to simplify information appropriate to farmers reading and numeracy skills. To improve education, more efforts could be made to develop and improve rural farmers' enrolment into formal/informal education. These could be in things like developing road infrastructure linking rural areas to the urban cities where schools are located and providing reasonably priced transportation, and in locating schools closer. It could also be useful to revise formal financial sector regulations to encourage outreach to rural areas with financial products that are safe and easy to understand. This could be done by locating finance institutions in proximal distances and placing emphasis on the mobilization of savings and deposits by offering a variety of savings opportunities that consider the differences in farmers' needs and constraints, ensuring that the poor among them can afford the minimum deposits. These institutions could consider the acceptance of both physical and social collateral. Besides, these institutions could conduct market research to have a broad understanding of the financial needs, and preferred products by rural farmers to develop financial services tailored to their needs. Because more rural farmers and females accessed credit from informal credit providers, consideration could be given to the provision of funding to informal lenders in rural communities for 
onward lending to community members. This will help to consolidate their strengths and mitigate their weaknesses. This is particularly important because most informal lenders are very experienced lenders with first-hand knowledge of their local clientele. However, they are very resource constrained and are therefore not able to lend to many borrowers. This could be achieved through the concept of credit layering in which formal lenders delegate loan provisions to downstream lenders who have better information on borrowers that generate high repayment rates (Rong et al., 2014). By this concept, informal lenders could be encouraged through the appropriate policy framework to act as communitylevel agents serving as intermediaries between borrowers in farming communities and the formal financial institutions based in the cities and towns across the country. This will help to minimize issues raised by proximity, simplify application and repayment procedures and processes, enhance timely credit delivery and reduce transaction costs. Overall, this framework will help in the delivery of affordable and convenient financial services to both lenders and borrowers. Also, it would be useful to design loan packages that would encourage rural farmers to engage in more profitable economic activities by bundling credit with additional support services like monitoring the progress of their productive activities and connecting them with agencies or groups that would support their productive activities. 


\section{References}

Abdulrahim, M. A., Muhammed -Lawal, A., Olasore, A. A., Oni, O. O. (2016). Assessment of Animal Protein Consumption and Food Security Among Rural Households in Kwara State, Nigeria. American Journal of Business and Society Vol. 1, No. 4, 2016, pp. 233-245 http://www.aiscience.org/journal/ajbs

Abedullah, N. M., Khalid, M. \& Kouser, S. (2009). The Role of agricultural credit in the growth of livestock sector: A case study of Faisalabad. Pakistan Veterinary Journal, 29,8184 .

Adeoye, S.O. and Ugalahi, U.B. (2017). Smallholder food crop farmers' participation in Bank of Agriculture (BOA) loan scheme in Ogun State, Nigeria. Agrosearch Vol. 17 No. 2: 51- 66. Available https://www.ajol.info/index.php/agrosh/article/view/163444

Adera, A. (1995). Instituting effective linkages between the formal and the informal financial sectors in Africa: a proposal. Savings and Development, 1, Pgs.5-27.

Akram, Z., Ajmal, S. and Munir, M. (2008) "Estimation of correlation coefficient among some yield parameters of wheat under rain fed conditions" Pakistan Journal of Botany, Vol. 40(4), pp. 1777- 81.

Akudugu, M. A. (2011). Rural banks' financial capital and livelihoods development of women farmers in Ghana. Journal of Enterprising Communities: People and Places in the Global Economy, 5, 248-264.

Akudugu, M. A. (2010). Assessment of access to financial capital by rural people in Ghana: The case of the Upper East Region. Savings and Development, 34, 169-189.

Akudugu, M. A., Egyir, I. S. \& Akwasi, M.-B. (2009a). Access to credit from rural banks in Ghana: The case of women farmers in the Upper East Region. Ghana Journal of Development Studies, 6, 142 - 167.

Akudugu, M. A., Egyir, I. S. \& Akwasi, M.-B. (2009b). Women farmers' access to credit from rural banks in Ghana. Agricultural Finance Review, 69, 284 - 299. Alliance for a Green Revolution in Africa (AGRA) (2012): From strength to strength; Growing Africa's Agriculture

Anyanwu, C.M. (2004). Microfinance institutions in Nigeria: Policy, practice, and potentials. Paper presented at the G24 Workshop on "Constraints to Growth in Sub Saharan Africa," Pretoria, South Africa, November 29- 30, 2004.

Badiru, I. O. (2010). Review of Small Farmer Access to Agricultural Credit in Nigeria. Nigeria Strategy Support Program Policy Note. IFPRI, Supported by CGIAR. 
Bongomin, G., Munene, J., Ntayi, J. and Malinga, C. (2018). "Analyzing the relationship between institutional framework and financial inclusion in rural Uganda: A social network perspective", International Journal of Emerging Markets, Vol. 13 Issue: 4, pp.606-630, https://doi.org/10.1108/IJoEM-02-2017-0057

Central Bank of Nigeria (CBN), International Finance Corporation (IFC) and the World Bank (2017): The Credit Crunch; Nigerian Financial Literacy Baseline Survey. How the use of movable collateral and credit reporting can help finance inclusive economic growth in Nigeria?

Central Bank of Nigeria (CBN) (2014). Credit Delivery to Small and Medium Enterprises: Post Bank Consolidation in Nigeria. Real Sector Division Research Department Central Bank of Nigeria. October 2014 AUTHORS Charles N.O Mordi Cajetan M. Anyanwu Banji S. Adebusuyi Lawrence I. Odey Bandele A.G Amoo Ph.D Mbutor O. Mbutor Olugbenga M. Adebayo Nkereuwem I. Akpan Nkenchor N. Igue Derek Ibeagha Maximillian Belonwu Shettima T. Zimboh Ph.D.

Central Bank of Nigeria (CBN) (2008). Annual Report and Financial Statements for the Year Ended 31st December, 2008

Deb, R. \& Suri, T. (2013). Endogenous emergence of credit markets: Contracting in Response to a new technology in Ghana. Journal of Development Economics, 101, 268-283.

Emefesi, B.O. and Yusuf, B. (2014). Access and impact of micro credit on poverty alleviation among farmers in Kirfi Local Government Area of Bauchi State. IOSR Journal of Agriculture and Veterinary Science (IOSR-JAVS) e-ISSN: 2319-2380, p-ISSN: 23192372. Volume 7, Issue 11 Ver. I (Nov. 2014), PP 30-35 www.iosrjournals.org

Etonihu, K. I., Rahman, S. A. and Usman, S. (2013). Determinants of access to agricultural credit among crop farmers in a farming community of Nasarawa State, Nigeria. Global Journal of Agricultural Economics, Extension and Rural Development. Vol. 1 (1), pp. 060-064, November, 2013. Global Science Research Journals.

Famogbiele, A. (2013). The Challenges of Agricultural Finance in Nigeria: Constraints to Sustainable Agricultural and Economic Revival. International Journal of Business and Social Research (IJBSR), Volume -3, No.-5.

FAO (2017). Review of the Livestock and Milk Value Chains and Policy Influencing them in Nigeria. BY Ilu I. Y. Frank, A. \& Annatte, I. Edited by Olanrewaju B. Smith Abdou Salla Berhanu Bedane

Fletschner, D. (2009). Rural Women's Access to Credit: Market Imperfections and IntraHousehold Dynamics. World Development 
Fletschner, D. \& Kenny, L. (2011). Rural women's access to financial services: credit, Savings and insurance. The Food and Agriculture Organization of the United Nations.

FMARD (Federal Ministry of Agriculture and Rural Development) (2008). National FADAMA Development Office, Abuja, Nigeria

Germidis, D., Kessler, D., \& Meghir, R. (1991). Financial systems and development: What role for the formal and informal financial sectors? Paris, France: OECD Development Centre.

Girei, A. A., Ohen S. B., and Jimmy O.B. (2016). Income Analysis of Farmers with and without Access to Credit in Southern Agricultural Zone, Nasarawa State, Nigeria. International Journal of Environment, Agriculture and Biotechnology (IJEAB). Vol-1, Issue-4, Nov-Dec- 2016 http://dx.doi.org/10.22161/ijeab/1.4.55 ISSN: 2456-1878

Guiso, L., Viviano. E. (2015). How much can financial literacy help? Rev Finance 19(4):1347-1382. Doi: 10. 1093/rof/rfu033

Hanson D.L, and Menezes C.F. (1971). On a neglected aspect of the theory of risk aversion. Economic Enquiry: Volume 9, Issue 2. Pgs 115-229. Western Economic Association International

Hill, L., Kau P. (1973). Application of multivariate probit to a threshold model of grain dryer purchasing decisions, American Journal of Agricultural Economics, 55, 1927.

IFAD. (2006). Enabling the Rural Poor to Overcome Poverty in Nigeria. Available: http://www.ifad.org/operations/projects/regions/pa/factsheets/ng.pdf.

IFAD (2004). Livestock Services and the Poor. IFAD, DANIDA, World Bank, DAAS, University of Reading and national institutions in Bangladesh, Bolivia, Denmark, India and Kenya.

IFPRI (2014). Loan Demand and Rationing among Small-Scale Farmers in Nigeria. IFPRI Discussion Paper 01403 December 2014. Edited by Aderibigbe S. Olomola Kwabena Gyimah-Brempong.

Kokoye, S. E. H., Tovignan, S. D., Yabi, J. A. \& Yegbemey, R. N. (2013). Econometric modeling of farm household land allocation in the municipality of Banikoara in Northern Benin. Land Use Policy, 34, 72-79.

Kong, R., Turvey, C., Xiaolan, X., Fei, L. (2014). "Borrower attitudes, lender attitudes and agricultural lending in rural China", International Journal of Bank Marketing, Vol. 32 Issue: 2, pp.104-129 https://doi.org/10.1108/IJBM-08-2013-0087. 
Lukytawati, A. (2009). "Factors Influencing Participation and Credit Constraints of a Financial SelfHelp Group in a Remote Rural Area: The Case of ROSCA and ASCRA in Kemang Village West Java", Journal of Applied Sciences, Vol. 9(11), pp. 2067-77.

Marcus, N. D. \& Binbol, A. L. (2010). Geography of Nasarawa State: A study of Flora and Fauna. In: Akunwunmi, O., A. J. M., Onoja, A., Filabi, M. A., \& Iyamoga, C.O. (ed.) Studies in the History and Culture of the Peoples of Nasarawa State. Ahmadu Bello University Press Limited, Zaria. Nasarawa State University 2010.

Mudida, R. (2003). Modern Economics (Nairobi: Focus Publications Ltd).

NPC (2016). "Nigerian Population Now". National Population Commission Data for National Development. http://www.population.gov.ng/

Ojo, E. O. and Adebayo, P. F. (2012). Food security in Nigeria: An overview European Journal of Development. 1,2, $1999-222$.

Ogbuabor, J. E., and Nwosu C. A. (2017). The Impact of Deposit Money Bank's Agricultural Credit on Agricultural Productivity in Nigeria: Evidence from an Error Correction Model. International Journal of Economics and Financial Issues, 2017, 7(2), 513-517. available at http: www.econjournals.com

Okojie, C., A., Monye-Emina, K., Eghafona, G., \& Osaghae, J.O. (2010). Institutional environment and access to microfinance by self-employed women in the rural areas of Edo State. Washington. D.C.: International Food Policy Research Institute.

Ololade R.A. and Olagunju F.I. (2013): Determinants of Access to Credit among Rural Farmers in Oyo State, Nigeria. Global Journal of Science Frontier Research (D) $13(2), 17-22$

Owualah, S.I. (1999): Entrepreneurship in small business firm G-MAG investment Ltd. Ikeja, Lagos. p.67.

Philip, D., Nkoya, E., Pender, J. \& Ono, A. O. (2009). Constraints to increasing Agricultural Productivity in Nigeria. In: (NSSP), N. S. S. P. (ed.) Sustainable Solutions for ending Hunger and Poverty. International Food Policy Research Institute. IFPRI, Supported by CGIAR.

Pindyck, R. S., Rubinfeld, D. L. (1998). Econometric models and economic forecasts Business \& Economics - 634 pages.

Quisumbing, A. \& Pandolfelli, L. (2009). Promising Approaches to address the Needs of Poor Female Farmers. Washington, D.C. International Food Policy Research Institute. 
Rahman, S. A., Ajayi, F. A., Okunsebor, S. A. \& Yakubu, A. (2010). The Status of Agriculture in Nasarawa State in: Tinakunwunmi O., Ayuba J.M., Onoja A., Filabi M.A. \& C.O., I. (eds.) Studies in the History and Culture of the Peoples of Nasarawa State. Ahmadu Bello University Press Limited, Zaria, Nigeria: Nasarawa State University. Rathgeber, E. M. 1990. The "WID, WAD, GAD. (1990): Trends in Research and Practice. Journal of Developing Areas, 24 489-502.

Rahji, M. A. Y., and Fakayode, S. B. (2009). "A multinomial Logit Analysis of Agricultural Credit Rationing by Commercial Banks in Nigeria", International Research Journal of Finance and Economics, Issue number 24, pp. 90-100.

Rossi, A. \& Lambrou, Y. (2008). Gender and Equity Issues in Liquid Bio Fuels Productions: Minimizing the Risks to Maximize the Opportunities Rome: FAO.

Saka, J. O., Lawal, B. O., Waliyat, A., Balogun, O. L. \& Oyagbami, A. (2008). Effect of Group Participation on Access to Micro-Credit among Rural Women in Osun and Oyo States, Nigeria. Journal of Agricultural Extension, 121.

Saleemi, N. A. (2000). Economics Simplified (Nairobi: N.A. Saleemi Publishers).

Samson, A., \& Obademi, O. (2018). The determinants and impact of access to agricultural credit on productivity by farmers in Nigeria; Evidence from Oyo State, Nigeria. Advances in Social Sciences Research Journal, 5(3) 252-265.

Schindler, K. (2010). Credit for what? Informal credit as a coping strategy of market women in northern Ghana. Journal of Development Studies, 46, 234-253.

Silong, A.K.F. (2017). Credit and the Technical Efficiency of Sheep and Goat Production among Rural Female Farmers in Nasarawa State, Nigeria. Unpublished thesis Submitted in Fulfilment of the Requirements for the Degree of Doctor of Philosophy. The University of Reading Graduate Institute of International Development and Applied Economics (GIIDAE), School of Agriculture, Policy and Development

Tiken Das. (2018) "Does credit access lead to expansion of income and multidimensional poverty? A study of rural Assam", International Journal of Social Economics,_https://doi.org/10.1108/IJSE-12-2017-0592

Udoka, C. O., Mbat, D. O. and Duke, S. B. (2016). "The Effect of Commercial Banks' Credit on Agricultural Production in Nigeria", Journal of Finance and Accounting, 2016, Vol. 4, No. 1, 1-10. DOI:10.12691/jfa-4-1-1

World Bank (2017). Microfinance and Economic Development. Policy Research Working Paper 8252 Development Research Group Finance and Private Sector Development Team November 2017 
World Bank (2009). Minding the stock: bringing public policy to bear on livestock sector development. Washington, DC: 2009. Report no. 44010-GLB.

World Bank (2008a). World Development Report. Washington, DC.

Yan, J., Chen, C. and Hu, B. (2018) "Farm size and production efficiency in Chinese agriculture: output and profit", China Agricultural Economic Review, https://doi.org/10.1108/CAER-05-2018-0082 